\title{
ARTICLE
}

\section{Digital Images and Multivariate Calibration in the Determination of Rheological and Quality Parameters of Wheat Flour}

\author{
Leticia Darlla Cordeiro iD, Patrícia Valderrama* $\square$ \\ Universidade Tecnológica Federal do Paraná (UTFPR), Via Rosalina Maria dos Santos, 1233, Postal Code \\ 87301-899, Campo Mourão, PR, Brazil
}

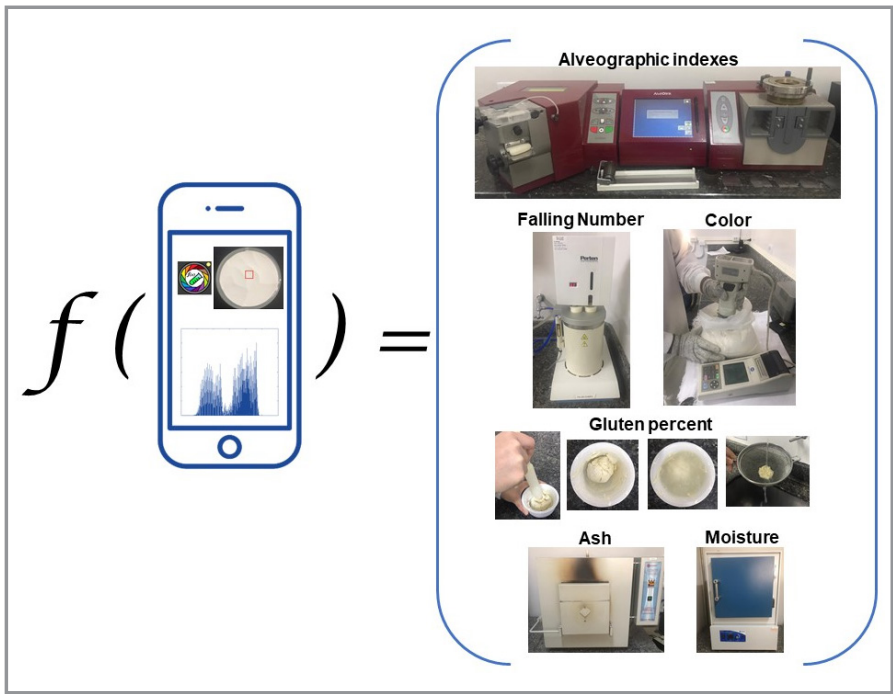

In this work, the quality and rheological parameters such as moisture, ash, color, falling number, gluten, and alveographic indexes (W, P/L, and $\mathrm{I} / \mathrm{E})$ were determined in wheat flour samples provided from the industrial process through digital images and multivariate calibration, based on partial least squares (PLS) regression. The models were validated by the evaluation of the figures of merit such as accuracy, the inverse of analytical sensitivity, adjust, linearity, relative prediction deviation, limits of detection, and quantification, indicating that the proposal is feasible and can be used in the industrial routine analysis as an alternative to the methods highly dependent on the analyst perception, and extremally time-consuming.

Keywords: gluten; falling number; alveographic indexes; PLS; validation.

\section{INTRODUCTION}

Wheat flour is a food matrix that containing proteins, carbohydrates, amino acids, dietary fiber, fat, water, minerals, vitamins [1], and it is the basic constituent, for example, of bread, pastries, biscuits, cakes, and pasta [2].

This food matrix arouses interest from the analytical viewpoint, based on legislation and other situations, as fraud, and contamination. According to the Brazilian legislation the Normative Instruction $n^{\circ} 8$ (Technical Regulation of Wheat Flour Identity and Quality) of Agriculture, Livestock and Supply Ministry, the moisture content of wheat flour must be up to $15 \%$, being wheat flour classified as Type 1, Type 2 and whole, according to the maximum ash content of $0.8 \%, 1.4 \%$ and $2.5 \%$ and protein content of at least $7.5 \%, 8.0 \%$, and $8.0 \%$, respectively [3].

Cite: Cordeiro, L. D.; Valderrama, P. Digital Images and Multivariate Calibration in the Determination of Rheological and Quality Parameters of Wheat Flour. Braz. J. Anal. Chem., 2021, 8 (32), pp 62-77. doi: http://dx.doi.org/10.30744/brjac.2179-3425.AR09-2021 
For quality and identity parameters, the traditional methods for moisture, color, ash, gluten percent, falling number, and alveographic indexes are based on the American Association of Cereal Chemists (AACC) [4]. On the other hand, it is possible to highlighting some alternative methods such as in the simultaneous determination of ash content and protein by using near-infrared (NIR) reflection spectroscopy, and diffuse reflectance infrared Fourier Transform (FT) spectroscopy [5,6]; in the determination of total protein and wet gluten [7], total phenolic content [8], fatty acid [9], and some other quality and rheological parameters [10] by using NIR spectroscopy; to predict the geographic origin of wheat flour by NIR spectroscopy [11]; for prediction of deoxynivalenol (DON) contamination [12], in the discrimination of talcum powder and benzoyl peroxide in wheat flour [13], and to detect low-level peanut powder contamination of whole wheat flour [14] by NIR hyperspectral imaging; in the quantification of total phenolics and ferulic acid using ultraviolet and visible (UV-Vis) spectrophotometry [15]; for quantification of gluten by FT-Raman spectroscopy [16]; for quantitative detection of adulterants with Raman hyperspectral imaging [17]; to investigate the correlations existing between the GlutoPeak indices and the conventional rheological parameters [2,18].

Notwithstanding some analytical techniques employed in the cited examples are expensive (as hyperspectral imaging) or demand sample preparation (as UV-Vis spectrophotometry). Furthermore, even with the relative cheapness of the NIR spectroscopy (especially the hand-held equipment), a digital image based on a smartphone it is even cheaper and no requires sample preparation, became possible the raw sample evaluation provided from the process.

The color of food is the first quality parameter evaluated by consumers and is thus a critical factor for acceptance of the food item by the consumer [19]. Concerning the wheat flour color, it can be influenced, for example, for wheat variety, aging, milling practices, and bleaching, in which the color ranging from brownish-grey to creamy yellow to the whitest white. The wheat flour color reflects the chemical composition and processing history of each flour batch influencing nutritional value and safety [20]. On the other hand, the color of any pixel of the image of an object can be registered using three color sensors per pixel through a digital camera. In this sense, each sensor captures the intensity of the light in the red (R), green $(G)$, or blue (B) spectrum, respectively, is the often-used color model [19]. The variables R, G, and B can assume values between 0 and 255. Then, each sample can generate a vector with dimensions $1 \times 768$ (256 possible values for R, G, and B variables placed side by side in that order) [21]. These signals are then used as descriptor variables in multivariate calibration models and were applied in different food matrix evaluation such as pesto sauce [22], commercial carbonated soft drinks [23,24], ripening bananas [25], potato chips [26], freeze-dried açai [27], and grape juice [28]. Regarding wheat flour, to the best of our knowledge, was not found paper that describes the application of image analysis coupled with multivariate calibration for evaluation of rheological and quality parameters in this matrix. Due to this, this work aimed to investigate digital images obtained from an iPhone for the determination of moisture, color, ash, gluten percent, falling number, and alveographic indexes in genuine samples of wheat flour coming from a process of a milling wheat industry.

\section{MATERIALS AND METHODS \\ Samples}

A total of 100 genuine wheat flour samples was utilized in this work. The samples were from a wheat flour industry located in the Paraná state, Brazil, and manufactured by this industry from December 2019 to January 2020. All the samples were genuine from the industrial process.

\section{Multivariate calibration}

A multivariate calibration through partial least squares (PLS) regression is proposed to correlate digital images with rheological and quality parameters: moisture (\%), color $\left(L^{*}\right)$, ash (\%), gluten percent $(\%)$, Falling Number (s), and alveographic indexes such as W (that represent the gluten 'strength' and is given by mechanical work, $10^{-4} \mathrm{~J}$ ), $\mathrm{P} / \mathrm{L}$ (the tenacity/extensibility ratio which expresses the mass balance, $\mathrm{mm}$ ), and IE (elasticity index, \%). 
The PLS' mathematical descriptions are presented in several manuscripts [29,30] and not detailed here. For the PLS model development, the $\mathbf{X}$ matrix (digital images $-\mathbf{X}$ block) was correlated to a $\mathbf{y}$ vector (y block), which contained the rheological and quality parameters determined by the reference methods in a PLS1 correlation (Details concerning $\mathbf{X}$ and $\mathbf{y}$ blocks below). The models were performed in MATLAB R2007B (The MathWorks Inc., Natick, USA) and PLS-Toolbox 5.2.

A total of 75 samples were employed in the calibration step, whereas 25 samples were used in the external validation step, all of them selected by the kenston algorithm [31]. Data were mean-centered, and the number of latent variables (LVs) was chosen based on the Root Mean Square Error of CrossValidation (RMSECV) through continuous blocks of 5 samples. The variance explained in the $\mathbf{y}$ block was also considered on chosen the number of LVs. It was as well considered the outliers evaluation based on leverage, unmodeled residuals in $\mathbf{X}$, and $\mathbf{y}$ blocks [32-35].

PLS models were validated by the determination of the parameters of merit such as accuracy, fit, linearity, residual prediction deviation, the inverse of analytical sensitivity, and limits of detection and quantification $[35,36]$, according to the equations presented in Table I.

Table I. Equations for parameters of merit

$\begin{array}{ll}\text { Parameters } & \text { Equations }\end{array}$

Accuracy

$$
\operatorname{RMSEC}=\sqrt{\frac{\sum\left(\mathrm{y}_{i}-\hat{\mathrm{y}}_{i}\right)^{2}}{n_{c}-n V L}} \text { and } \operatorname{RMSEP}=\sqrt{\frac{\sum\left(\mathrm{y}_{i}-\hat{\mathrm{y}}_{i}\right)^{2}}{n_{v}}}
$$

Sensitivity

$$
S E N=\frac{1}{\|\mathbf{b}\|}
$$

Analytical sensitivity

$$
S E N \_A=\frac{S E N}{\delta x}
$$

Analytical sensitivity ${ }^{-1}$

$$
S E N \_A^{-1}=\frac{1}{S E N \_A}
$$

Limit of detection

$$
L D=3.3 \delta x\|\mathbf{b}\|=3.3 \delta x \frac{1}{S E N}
$$

\section{Limit of quantification}

$$
L Q=10 \delta x\|\mathbf{b}\|=10 \delta x \frac{1}{S E N}
$$

$\mathrm{RPD}_{\text {cal }}$

$$
R P D_{c a l}=\frac{D P_{c a l}}{R M S E C V}
$$

$\mathrm{y}_{\mathrm{i}}$ is the reference value of sample $i ; \hat{y}_{i}$ is the predicted value of sample $i ; \mathrm{n}_{\mathrm{c}}$ is the number of samples in the calibration set; $n_{v}$ is the number of samples in the external validation set; $n V L$ is the number of latent variables. $\mathbf{b}$ is the regression coefficients vector; $\delta x$ is estimative for the instrumental noise; $\mathrm{DP}_{\text {cal }}$ is the standard deviation of reference values in the calibration set; RMSECV is the root mean square error of cross-validation; Observation: In the equation for RMSEC, it is employed " $\mathrm{c}_{\mathrm{c}}-\mathrm{nVL}+1$ " when the data are mean-centered. 


\section{Images acquire (X block)}

An iPhone 7 Plus (Apple Inc.) with 12 megapixels resolution, automatic High Dynamic Range (HDR), without flash, was used to capture the images at the moment when the samples arrived from the industrial process to perform the reference analysis on the industrial laboratory.

The distance from the camera to the wheat flour sample ( $20 \mathrm{~g}$ in a petri dish with $5 \mathrm{~cm}$ diameter) was 20 $\mathrm{cm}$ and the smartphone was kept in fixed support. The same lighting conditions (2 led lamps with 20 watts each in a $32 \mathrm{~m}^{2}$ environment, temperature around $20^{\circ} \mathrm{C}+/-3^{\circ} \mathrm{C}$ ) were kept during image acquisition.

The images were captured by the PhotoMetrix ${ }^{\circledR}$ [37] app in the form of the histogram whose generates a response vector related to the channels $\mathrm{R}$ (red), $\mathrm{G}$ (green), and B (blue). A total of six replicates were done for each sample, and a mean was used for the multivariate model development. So, the R, G, and $B$ vectors (in which for each vector the dimensions were $1 \times 768$, i.e., 256 possible values for $R, G$, and $B$ variables placed side by side in that order) were organized into a matrix (100x768).

\section{Reference analysis (y block)}

The reference methods for rheological and quality parameters determination were according to the American Association of Cereal Chemists (AACC) [4] and summarized in Table II. It is important to highlight the time dispended in the analysis of some parameters, as well as high dependence on the analyst perception.

Table II. Reference methods for rheological and quality parameters of wheat flour

\begin{tabular}{|c|c|}
\hline Parameters & Description \\
\hline Moisture & $\begin{array}{l}\text { Moisture content followed the AACC } 44-15.02 \text { method, where the samples } \\
\text { were dehydrated in an oven at } 130^{\circ} \mathrm{C}+/-2^{\circ} \mathrm{C} \text {, until constant weight. Analysis } \\
\text { time around } 4 \text { hours. }\end{array}$ \\
\hline Color & $\begin{array}{l}\text { Luminosity }\left(\mathrm{L}^{*}\right) \text { followed the AACC } 14-22.01 \text { method by using a Minolta } \\
\text { colorimeter equipment. }\end{array}$ \\
\hline Ash & $\begin{array}{l}\text { Ash followed the AACC } 08-02.01 \text { method where the samples were subjected } \\
\text { to the dry matter combustion in a muffle at } 600{ }^{\circ} \mathrm{C}+/-5{ }^{\circ} \mathrm{C} \text {. Analysis time }=5 \\
\text { hours. }\end{array}$ \\
\hline Gluten percent & $\begin{array}{l}\text { Gluten percent follower the AACC } 38-12.02 \text { method where the wheat flour } \\
\text { sample }(5 \mathrm{~g}) \text { is weighed and mixed with } 10 \mathrm{~mL} \text { of } 5 \% \text { aqueous sodium chloride } \\
\text { solution. The dough was rest for } 30 \text { minutes, and then, water was added } \\
\text { until it was covered and the dough rest again for another } 30 \text { minutes. The } \\
\text { agglomerate obtained is washed with water over a } 100-\text { mesh sieve, pressing } \\
\text { lightly with hands. Washing continued until the water was no longer whitish. The } \\
\text { remaining dough was weighed, and gluten percentage calculated by [gluten } \\
(\%)=\text { dry gluten mass }(\mathrm{g}) .100 / \text { sample mass }(\mathrm{g}) \text { ]. Analysis time }=60 \text { minutes. }\end{array}$ \\
\hline
\end{tabular}

Falling Number (FN)

Alveographic indexes
FN followed the AACC 56-81B method and the result is obtained utilizing an instrument (PerkinElmer model 1310), based on principles of viscosimetry, that determines the amylolytic activity of the wheat flour. Analysis time $=15$ minutes.

W, P/L, and IE followed the AACC 54-30.02 method by using an Alveograph Chopin equipment (model 171), where $250 \mathrm{~g}$ of wheat flour sample were weighed and $135 \mathrm{ml}$ of $2.5 \%$ saline solution was added. The dough was homogenized for 8 minutes. The total time from the start to the end of alveographic analysis is around 60 minutes. 


\section{RESULTS AND DISCUSSION}

The R, G, B vectors obtained for the wheat flour samples are shown in Figure 1(A). For each vector, 768 variables were obtained (i.e., 256 possible values for $R, G$, and $B$ placed side by side in that order). The $R$ and $G$ regions were removed due to in this region no relevant information is present (i.e., zero intensity). Figure 1(B) presents the $B$ vectors of wheat flour samples, that were organized into a matrix $(100 \times 256)$ and used to build the models.

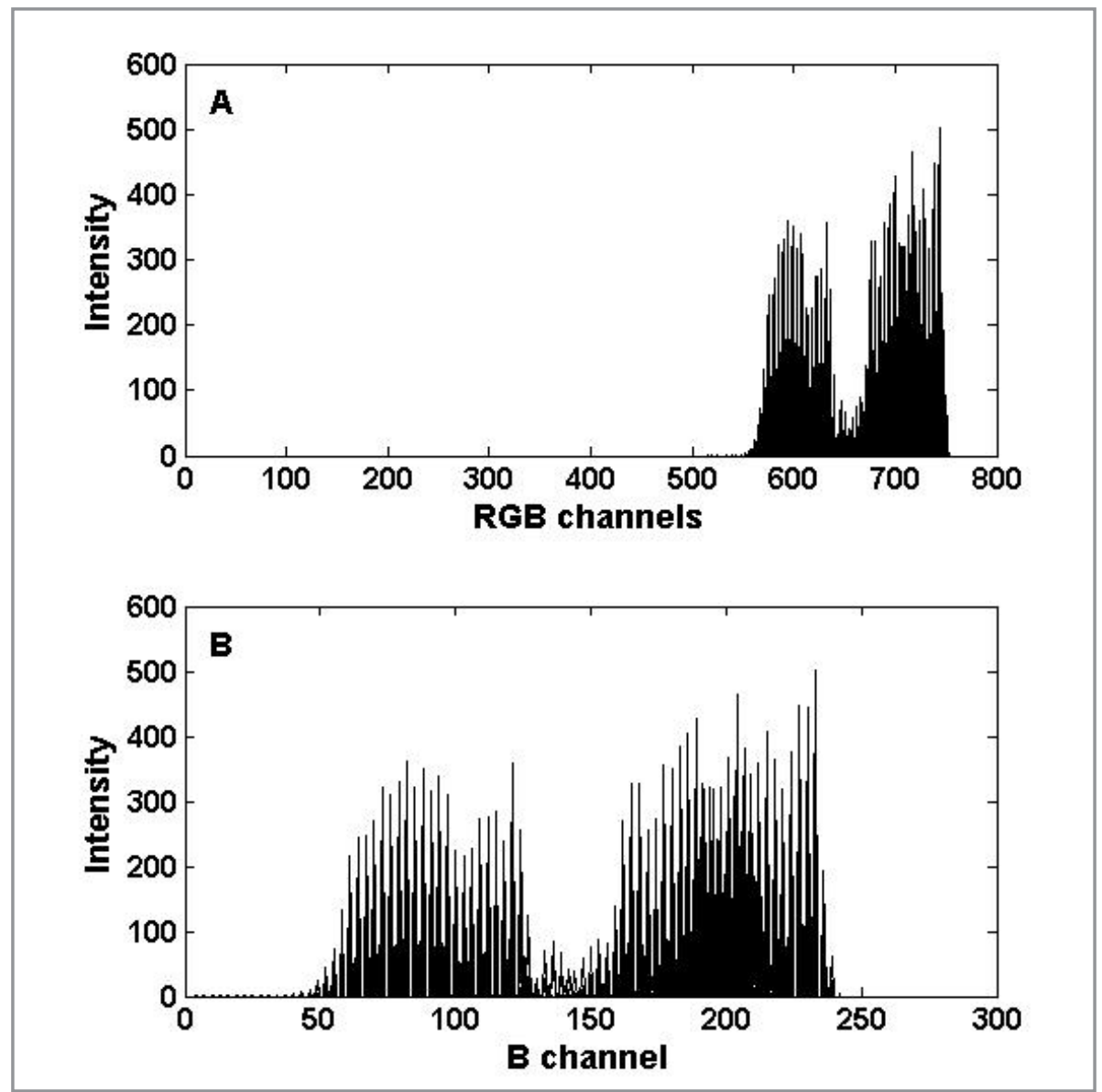

Figure 1. R, G, B vectors of wheat flour samples.

After splitting the data into calibration and external validation samples, in order to improve the model's quality, the first step in model development was outlier evaluation. Outliers were evaluated only one round and removed based on leverage, unmodeled residuals in $\mathbf{X}$, and $\mathbf{y}$ blocks.

The optimum model dimension necessary to retain a significant variance in the data resulted in the number of LVs and parameters of merit present in Table III.

The Root Mean Squared Error of Calibration (RMSEC) and Prediction (RMSEP) are accuracy indicators. Those values report the closeness of agreement between the reference value (obtained by reference analysis - Table 1S in the supplementary material) and the value found by the PLS model. Despite the high number of LVs in some cases, the RMSEC and RMSEP values are also indicators of the properly chosen, since these parameters presented close results in each model $[6,38]$. Also, some modeled parameters such as gluten present a series of subjective steps, which can contribute to this demand for a higher number of LVs. 
The achieved accuracy results for FN, W, P/L, and gluten are lower than those obtained through models based on NIR/PLS $[7,10,16]$. On the other hand, related accuracy was obtained for ash in this proposal and on a model based on MIR/PLS [5].

Another way to verify the models' accuracy is the adjust $[32,33,35]$, represented by the plot of the rheological and quality parameters determined by reference analysis against those determined by the image/PLS model (Figure 2, and correlation coefficient in Table I). Comparing to the literature [6,7], the results for the correlation coefficient achieved with digital images/PLS are similar and higher when compared to models developed from NIR/PLS to determine ash and gluten, respectively in wheat flour.

The steps in PLS model development become the inverse of analytical sensitivity (analytical sensitivity ${ }^{-1}$ ) more suitable for evaluating the sensitivity of this multivariate calibration model. This parameter of merit allows the establishment of a minimum difference, which is discernible by the model in the modeled range of the interesting property $[33,35,36]$. Based on this, it is possible, to distinguish wheat flour samples with a difference of $0.1140 \%, 0.2775\left(\mathrm{~L}^{*}\right), 0.0395 \%, 3.1409 \mathrm{~s}, 0.4270 \%, 11.2570 \times 10^{-4} \mathrm{~J}, 0.1580 \mathrm{~mm}$, and $0.6780 \%$ for moisture, color, ash, FN, gluten, W, P/L, and IE, respectively.

Limits of detection and quantification for the PLS models show coherent results with the measured quantities (modeled range) and the achieved accuracy. Therefore, the PLS models are appropriate, for example, to detect until around $0.38 \%$ and quantify $1.14 \%$ of moisture in wheat flour, and these results are adequate for this quality parameter since it must be up to $15 \%$, according to the Brazilian legislation [3], and the modeled range for moisture was from 12.40 to $14.40 \%$. So, the model presents low limits of detection and quantification.

The predictive capacity of the PLS models was evaluated through the residual prediction deviation (RPD), which results from 1.5 to 2.4 are considered satisfactory [39]. In the evaluation of the RPD values for the calibration sets, all the models presented results inside that range. These results suggest that PLS models have an excellent forecasting capability, which is fundamental when the multivariate models can be applied to quality and process control [32].

The models' linearity was evaluated by the residuals plot (Figure $1 \mathrm{~S}$ in Supplementary material). The Jarque-Bera statistical test was employed to confirm the linearity of the developed models. In this test, when the JBSTAT values are lower than those of CRITICAL, it is considered that the residues exhibit a random behavior at a 95\% significance, indicating linearity for the PLS models [32,33]. For the developed models all of them presented JBSTAT values inferior to those of CRITVAL confirming that the errors present a random behavior and that the data fit on a linear model as PLS. Furthermore, to identify the most significant variables in the B channel that contribute for the model's development, the variable importance in projection (VIP) scores were calculated (Figure 2S in Supplementary material). The VIP scores are computed based on the scores samples, regression coefficients, and weight of the variables, considering the number of LVs involved in the model. VIP scores result greater than one is generally used as a criterion to identify the most significant variables [40]. In general, the B channel variables around $55-120$, and 155 - 240 were important for most of the models.

The results obtained for the parameters of merit showed that the proposed method based on image/ PLS can be feasible. Furthermore, this approach can contribute to the wheat flour industry especially in terms of quickness, analysis time, besides cost reduction. 
Table III. Parameters of merit

\begin{tabular}{|c|c|c|c|c|c|c|c|c|c|}
\hline Parameters of merit & & $\begin{array}{c}\text { Moisture } \\
(\%)\end{array}$ & $\begin{array}{c}\text { Color } \\
\left(L^{*}\right)\end{array}$ & $\begin{array}{l}\text { Ash } \\
(\%)\end{array}$ & $\begin{array}{l}\text { FN } \\
(\mathbf{s})\end{array}$ & $\begin{array}{c}\text { Gluten } \\
(\%)\end{array}$ & $\begin{array}{c}W \\
\left(10^{-4} \mathrm{~J}\right)\end{array}$ & $\begin{array}{c}\text { P/L } \\
(\mathrm{mm})\end{array}$ & $\begin{array}{l}\text { IE } \\
(\%)\end{array}$ \\
\hline & RMSEC & 0.2217 & 0.4862 & 0.0563 & 5.6754 & 0.6783 & 20.7134 & 0.2369 & 1.3364 \\
\hline Accuracy & RMSEP & 0.2802 & 0.5090 & 0.0718 & 5.3664 & 0.7194 & 26.1266 & 0.2923 & 1.2197 \\
\hline Correlation coefficient & & 0.7738 & 0.7615 & 0.7833 & 0.7442 & 0.7823 & 0.7276 & 0.7653 & 0.7636 \\
\hline Number of LVs & & 12 & 11 & 13 & 10 & 20 & 10 & 10 & 11 \\
\hline Range modeled & & $12.40-14.40$ & $90.23-93.40$ & $0.40-0.84$ & $337-386$ & $24.72-31.01$ & $228-386$ & $0.51-2.98$ & $50.87-62.40$ \\
\hline Analytical sensitivity ${ }^{-1}$ & & 0.1140 & 0.2775 & 0.0395 & 3.1409 & 0.4270 & 11.2579 & 0.1580 & 0.6780 \\
\hline Limit of detection & & 0.3761 & 0.9158 & 0.1302 & 10.3651 & 1.4091 & 37.1512 & 0.5214 & 2.2374 \\
\hline Limit of quantification & & 1.1397 & 2.7753 & 0.3946 & 31.4095 & 4.2700 & 112.5795 & 1.5800 & 6.7801 \\
\hline RPD $_{\text {cal }}$ & & 1.9468 & 1.9072 & 1.9696 & 1.8573 & 1.8605 & 1.7997 & 1.9371 & 1.9089 \\
\hline $\begin{array}{l}\text { Linearity (JBSTAT/ } \\
\text { CRITVAL) }\end{array}$ & & $\begin{array}{r}1.1985 \\
/ 3.6234\end{array}$ & $\begin{array}{c}0.6917 \\
/ 3.7156\end{array}$ & $\begin{array}{r}1.4226 \\
/ 2.8784\end{array}$ & $\begin{array}{r}1.2758 \\
/ 3.2985\end{array}$ & $\begin{array}{r}3.2985 \\
15.8862\end{array}$ & $\begin{array}{r}0.8245 \\
12.8784\end{array}$ & $\begin{array}{r}1.3765 \\
/ 3.4158\end{array}$ & $\begin{array}{c}1.0047 \\
/ 3.6234\end{array}$ \\
\hline
\end{tabular}




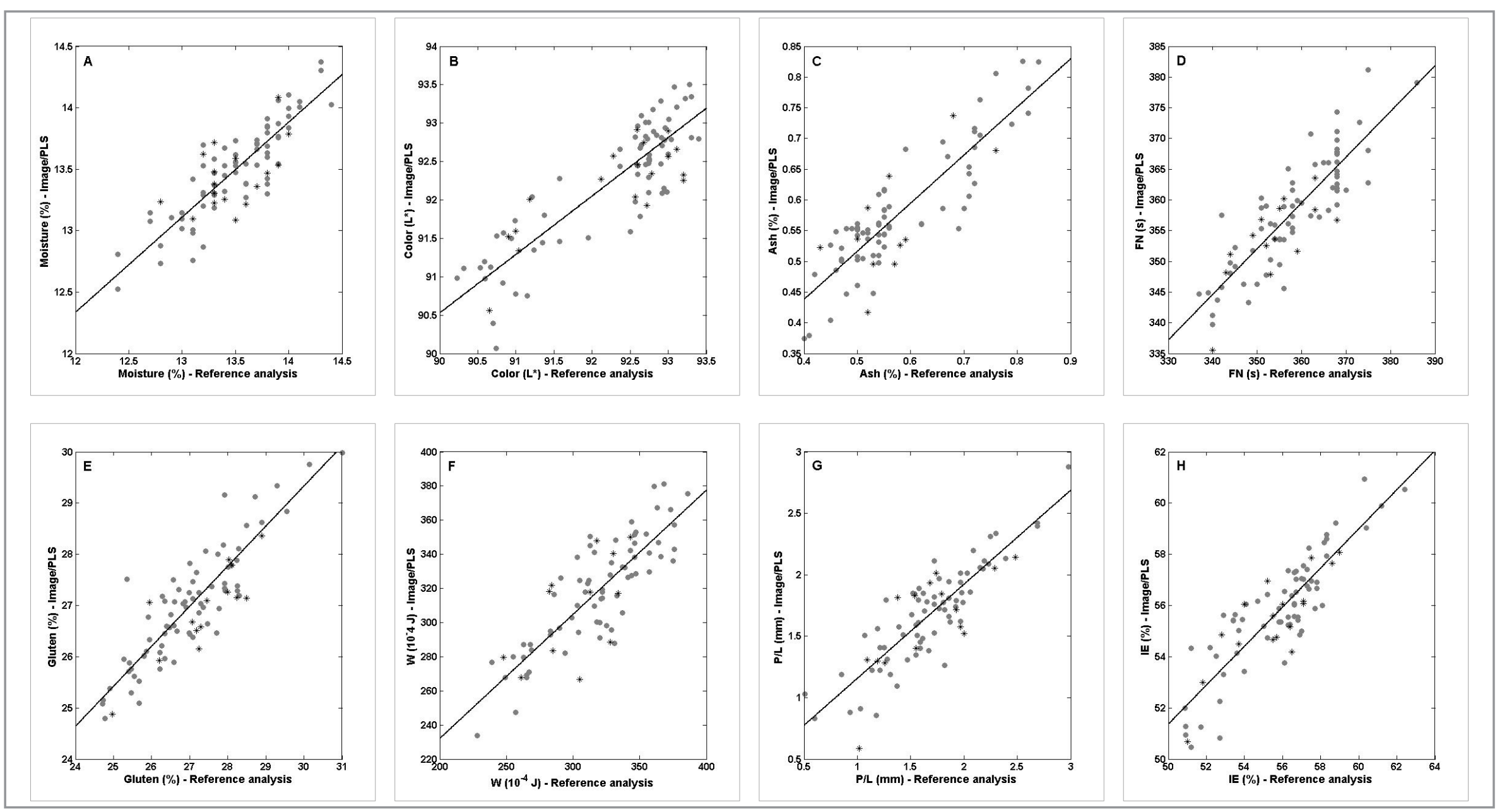

Figure 2. Adjust. (A) Moisture. (B) Color. (C) Ash. (D) FN. (E) Gluten. (F) W. (G) P/L. (H) IE. (•) calibration samples. (*) external validation samples. 


\section{CONCLUSIONS}

Image analysis coupled with the PLS model is suitable to determine rheological and quality parameters in the wheat flour samples provided from the industrial process. The models were validated by the parameters of merit showing promising and feasible results. The property values achieved for accuracy, predictive capacity, limits of detection, and quantification indicates that the image/PLS models can be an alternative to reference analysis performed currently by the industry. Moreover, the image/PLS models present several advantages compared to the reference methods. They use a small quantity of wheat flour sample, which is non-destructive, does not generate residues during the analysis, besides the quickness and lower dependence on the analyst perception.

\section{Conflicts of interest}

The authors declare no conflicts of interest.

\section{Acknowledgements}

The authors are grateful to the industry that provide the samples. Patrícia Valderrama acknowledges CNPq [process 306606/2020-8], and Professor Ronei Jesus Poppi for his knowledge, friendship, confidence, and empathy... a Professor and Friend that will be missed in this world.

\section{REFERENCES}

1. Sindhu, R.; Shiburaj, S.; Sabu, A.; Fernandes, P.; Singhal, R.; Mathew, G. M.; Nair, I. C.; Jayachandran, K.; Vidya, J.; Vandenberghe, L. P. S.; et al. Enzyme Technology in Food Processing: Recent Developments and Future Prospects. In: Knoerzer, K.; Muthukumarappan, K. (Eds.). Innovative Food Processing Technologies. Elsevier, Oxford, 2021, Vol. 3.12, pp 191-215 (https://doi.org/https://doi.org/10.1016/B978-0-12-8157817.00016-0).

2. Marti, A.; Ulrici, A.; Foca, G.; Quaglia, L.; Pagani, M. A. LWT - Food Sci. Technol., 2015, 64, pp 95-103 (https://doi.org/https://doi.org/10.1016/j.lwt.2015.05.029).

3. Instrução Normativa 8/2005. Regulamento técnico de identidade e qualidade da farinha de trigo. Ministério da Agricultura, Pecuária e Abastecimento, Brazil. 2005. Available at: https://www.gov. br/agricultura/pt-br/assuntos/inspecao/produtos-vegetal/legislacao-1/normativos-cgqv/pocs/instrucaonormativa-no-8-de-02-de-junho-de-2005-farinha-de-trigo/view [Accessed March 2021].

4. AACC Approved Methods of Analysis, American Association of Cereal Chemists, $11^{\text {th }}$ edition, Cereals \& Grains Association, St. Paul, MN, U.S.A. 2000.

5. Ferrão, M. F.; Davanzo, C. U. Anal. Chim. Acta, 2005, 540, pp 411-415 (https://doi.org/10.1016/j. aca.2005.03.038).

6. Ferrão, M. F.; Carvalho, C. W.; Müller, E. I.; Davanzo, C. U. Ciência e Tecnol. Aliment., 2004, 24, pp 333-340 (https://doi.org/10.1590/s0101-20612004000300005).

7. Chen, J.; Zhu, S.; Zhao, G. Food Chem., 2017, 221, pp 1939-1946 (https://doi.org/10.1016/j. foodchem.2016.11.155).

8. Tian, W.; Chen, G.; Zhang, G.; Wang, D.; Tilley, M.; Li, Y. Food Chem., 2021, 344, pp 128633 (https:// doi.org/10.1016/j.foodchem.2020.128633).

9. Jiang, H.; Liu, T.; Chen, Q. Infrared Phys. Technol., 2020, 109, pp 103423 (https://doi.org/10.1016/j. infrared.2020.103423).

10. Barbon Junior, S.; Mastelini, S. M.; Barbon, A. P. A. C.; Barbin, D. F.; Calvini, R.; Lopes, J. F.; Ulrici, A. Inf. Process. Agric., 2020, 7, pp 342-354 (https://doi.org/10.1016/j.inpa.2019.07.001).

11. González-Martín, M. I.; Wells Moncada, G.; González-Pérez, C.; Zapata San Martín, N.; LópezGonzález, F.; Lobos Ortega, I.; Hernández-Hierro, J.-M. Food Chem., 2014, 145, pp 802-806 (https:// doi.org/10.1016/j.foodchem.2013.08.103).

12. Zhao, T.; Chen, M.; Jiang, X.; Shen, F.; He, X.; Fang, Y.; Liu, Q.; Hu, Q. Infrared Phys. Technol., 2020, 109, 103426 (https://doi.org/10.1016/j.infrared.2020.103426). 
13. Fu, X.; Chen, J.; Fu, F.; Wu, C. Biosyst. Eng., 2020, 190, pp 120-130 (https://doi.org/10.1016/j. biosystemseng.2019.12.006).

14. Zhao, X.; Wang, W.; Ni, X.; Chu, X.; Li, Y.-F.; Lu, C. Biosyst. Eng., 2019, 184, pp 55-68 (https://doi. org/10.1016/j.biosystemseng.2019.06.010).

15. Tian, W.; Chen, G.; Gui, Y.; Zhang, G.; Li, Y. Food Control, 2020, 107691 (https://doi.org/10.1016/j. foodcont.2020.107691).

16. Czaja, T.; Mazurek, S.; Szostak, R. Food Chem., 2016, 211, pp 560-563 (https://doi.org/10.1016/j. foodchem.2016.05.108).

17. Lohumi, S.; Lee, H.; Kim, M. S.; Qin, J.; Cho, B.-K. Biosyst. Eng., 2019, 181, pp 103-113 (https://doi. org/10.1016/j.biosystemseng.2019.03.006).

18. Zawieja, B.; Makowska, A.; Gutsche, M. J. Cereal Sci., 2020, 91, 102898 (https://doi.org/10.1016/j. jcs.2019.102898).

19. León, K.; Mery, D.; Pedreschi, F.; León, J. Food Res. Int., 2006, 39, pp 1084-1091 (https://doi. org/10.1016/j.foodres.2006.03.006).

20. Hardy, A. C.; Cole, P. I.; Ricker, C. W. Ind. Eng. Chem. Anal. Ed., 1929, 1, pp 151-152 (https://doi. org/10.1021/ac50067a018).

21. Valderrama, L.; Março, P. H.; Valderrama, P. J. Chemom., 2020, 34, e3265 (https://doi.org/10.1002/ cem.3265).

22. Foca, G.; Masino, F.; Antonelli, A.; Ulrici, A. Anal. Chim. Acta, 2011, 706, pp 238-245 (https://doi. org/10.1016/j.aca.2011.08.046).

23. Botelho, B. G.; Assis, L. P.; Sena, M. M. Food Chem., 2014, 159, pp 175-180 (https://doi.org/10.1016/j. foodchem.2014.03.048).

24. Godinho, M. S.; Pereira, R. O.; Ribeiro, K. O.; Schimidt, F.; Oliveira, A. E.; Oliveira, S. E. Quim. Nova, 2008, 31, pp 1485-1489 (https://doi.org/10.1590/S0100-40422008000600039).

25. Mendoza, F.; Aguilera, J. M. J. Food Sci., 2004, 69, pp E471-E477 (https://doi. org/10.1111/j.1365-2621.2004.tb09932.x).

26. Edreschi, F. P.; Mery, D.; Mendoza, F.; Aguilera, J. M. J. Food Sci., 2004, 69, pp E264-E270 (https:// doi.org/10.1111/j.1365-2621.2004.tb10996.x).

27. Caramês, E. T. dos S.; Baqueta, M. R.; Conceição, D. A.; Pallone, J. A. L. Food Res. Int., 2021, 140, 109792 (https://doi.org/10.1016/j.foodres.2020.109792).

28. Beltrame, K. K.; Gonçalves, T. R.; Março, P. H.; Gomes, S. T. M.; Matsushita, M.; Valderrama, P. Aust. J. Grape Wine Res., 2019, 25, pp 156-160 (https://doi.org/10.1111/ajgw.12387).

29. Geladi, P.; Kowalski, B. R. Anal. Chim. Acta, 1986, 185, pp 1-17.

30. Wold, S.; Sjöström, M.; Eriksson, L. Chemom. Intell. Lab. Syst., 2001, 58, pp 109-130 (https://doi. org/10.1016/S0169-7439(01)00155-1).

31. Kennard, R. W.; Stone, L. A. Technometrics, 1969, 11, pp 137-148 (https://doi.org/10.2307/1266770).

32. Baqueta, M. R.; Coqueiro, A.; Valderrama, P. J. Food Sci., 2019, 84, pp 1247-1255 (https://doi. org/10.1111/1750-3841.14617).

33. Beltrame, K. K.; Souza, A. M.; Coelho, M. R.; Winkler, T. C. B.; Souza, W. E.; Valderrama, P. J. Braz. Chem. Soc., 2016, 27, pp 1527-1532 (https://doi.org/10.5935/0103-5053.20160031).

34. American Society for Testing Materials. ASTM E1655-17. Standard Practices for Infrared Multivariate Quantitative Analysis. ASTM, PA, USA, 2017.

35. Santos, D. A.; Lima, K. P.; Março, P. H.; Valderrama, P. J. Braz. Chem. Soc., 2016, 27, pp 1912-1917. (http://dx.doi.org/10.5935/0103-5053.20160071).

36. Ferreira, M. M. C. Quimiometria: conceitos, métodos e aplicações. Editora da Unicamp, Campinas, SP, 2015. Chapter 4, p 388.

37. Helfer, G. A.; Magnus, V. S.; Böck, F. C.; Teichmann, A.; Ferrão, M. F.; Da Costa, A. B. J. Braz. Chem. Soc., 2017, 28, pp 328-335 (https://doi.org/10.5935/0103-5053.20160182). 
38. Santos, D. A.; Coqueiro, A.; Gonçalves, T. R.; Carvalho, J. C.; Bezerra Jr., J. S.; Matsushita, M.; Oliveira, C. A. L.; Março, P. H.; Valderrama, P.; Ribeiro, R. P. J. Braz. Chem. Soc., 2020, 31, pp 18831890 (https://dx.doi.org/10.21577/0103-5053.20200082).

39. Botelho, B. G.; Mendes, B. A. P.; Sena, M. M. Quim. Nova, 2013, 36, pp 1416-1422 (https://doi. org/10.1590/S0100-40422013000900023).

40. Vitale, R.; Bevilacqua, M.; Bucci, R.; Magrì, A. D.; Magrì, A. L.; Marini, F. Chemom. Intell. Lab. Syst., 2013, 121, pp 90-99 (https://doi.org/10.1016/j.chemolab.2012.11.019).

\section{SUPPLEMENTARY MATERIAL}

Table S1. Reference values obtained by AACC methods

\begin{tabular}{|c|c|c|c|c|c|c|c|c|}
\hline $\begin{array}{l}\text { Sample } \\
\text { number }\end{array}$ & $\begin{array}{c}\text { Moisture } \\
\text { (\%) }\end{array}$ & $\begin{array}{l}\text { Color } \\
\left(L^{*}\right)\end{array}$ & $\begin{array}{l}\text { Ash } \\
\text { (\%) }\end{array}$ & $\begin{array}{l}\text { FN } \\
\text { (s) }\end{array}$ & $\begin{array}{c}\text { Gluten } \\
(\%)\end{array}$ & $\begin{array}{c}W \\
\left(10^{-4} \mathrm{~J}\right)\end{array}$ & $\begin{array}{c}P / L \\
(\mathrm{~mm})\end{array}$ & $\begin{array}{l}\text { IE } \\
(\%)\end{array}$ \\
\hline 1 & 14.0 & 92.68 & 0.43 & 355 & 26.21 & 391 & 1.54 & 59.0 \\
\hline 2 & 14.0 & 92.68 & 0.43 & 355 & 26.21 & 391 & 1.54 & 59.0 \\
\hline 3 & 13.8 & 92.94 & 0.49 & 349 & 25.36 & 303 & 2.17 & 57.8 \\
\hline 4 & 13.3 & 90.53 & 0.67 & 368 & 27.42 & 283 & 1.27 & 51.2 \\
\hline 5 & 13.2 & 92.85 & 0.54 & 366 & 25.41 & 344 & 1.86 & 53.7 \\
\hline 6 & 12.7 & 90.91 & 0.71 & 339 & 27.91 & 294 & 1.61 & 56.9 \\
\hline 7 & 13.2 & 90.75 & 0.66 & 368 & 25.54 & 357 & 0.92 & 52.5 \\
\hline 8 & 13.2 & 90.90 & 0.71 & 356 & 27.45 & 240 & 0.72 & 45.3 \\
\hline 9 & 13.4 & 93.30 & 0.46 & 368 & 25.94 & 364 & 1.99 & 56.3 \\
\hline 10 & 14.1 & 92.75 & 0.56 & 350 & 25.81 & 346 & 1.86 & 60.3 \\
\hline 11 & 13.8 & 90.94 & 0.76 & 342 & 26.57 & 290 & 1.37 & 51.7 \\
\hline 12 & 13.9 & 92.63 & 0.50 & 352 & 26.34 & 322 & 2.69 & 56.1 \\
\hline 13 & 13.6 & 92.75 & 0.50 & 356 & 25.81 & 291 & 2.92 & 53.4 \\
\hline 14 & 13.1 & 92.78 & 0.50 & 363 & 28.39 & 330 & 1.79 & 55.7 \\
\hline 15 & 13.1 & 93.28 & 0.52 & 368 & 24.73 & 361 & 1.86 & 57.1 \\
\hline 16 & 12.8 & 90.32 & 0.82 & 344 & 27.18 & 269 & 0.92 & 50.9 \\
\hline 17 & 13.0 & 91.57 & 0.62 & 356 & 27.46 & 267 & 1.93 & 53.6 \\
\hline 18 & 13.7 & 92.28 & 0.68 & 352 & 27.25 & 334 & 2.33 & 57.1 \\
\hline 19 & 14.0 & 92.37 & 0.54 & 342 & 25.47 & 313 & 1.72 & 56.7 \\
\hline 20 & 13.7 & 92.81 & 0.56 & 366 & 25.67 & 332 & 1.52 & 53.4 \\
\hline
\end{tabular}


Table S1. Reference values obtained by AACC methods (Continuation)

\begin{tabular}{|c|c|c|c|c|c|c|c|c|}
\hline $\begin{array}{l}\text { Sample } \\
\text { number }\end{array}$ & $\begin{array}{c}\text { Moisture } \\
(\%)\end{array}$ & $\begin{array}{l}\text { Color } \\
\left(L^{*}\right)\end{array}$ & $\begin{array}{l}\text { Ash } \\
\text { (\%) }\end{array}$ & $\begin{array}{l}\text { FN } \\
\text { (s) }\end{array}$ & $\begin{array}{c}\text { Gluten } \\
(\%)\end{array}$ & $\begin{array}{c}W \\
\left(10^{-4} \mathrm{~J}\right)\end{array}$ & $\begin{array}{c}P / L \\
(\mathrm{~mm})\end{array}$ & $\begin{array}{l}\text { IE } \\
(\%)\end{array}$ \\
\hline 21 & 13.2 & 92.95 & 0.45 & 368 & 24.91 & 363 & 2.15 & 57.4 \\
\hline 22 & 13.6 & 91.21 & 0.71 & 351 & 27.58 & 272 & 1.39 & 54.1 \\
\hline 23 & 13.3 & 92.57 & 0.42 & 344 & 25.67 & 265 & 1.97 & 54.0 \\
\hline 24 & 14.3 & 91.95 & 0.53 & 375 & 28.02 & 328 & 1.87 & 56.8 \\
\hline 25 & 13.6 & 91.14 & 0.77 & 340 & 27.18 & 328 & 1.38 & 52.8 \\
\hline 26 & 13.9 & 92.59 & 0.54 & 404 & 28.26 & 318 & 1.51 & 57.5 \\
\hline 27 & 13.3 & 91.20 & 0.78 & 345 & 27.08 & 322 & 1.65 & 51.2 \\
\hline 28 & 13.5 & 92.59 & 0.54 & 404 & 28.26 & 318 & 1.51 & 57.5 \\
\hline 29 & 13.3 & 92.57 & 0.42 & 344 & 25.67 & 265 & 1.97 & 54.0 \\
\hline 30 & 14.0 & 92.37 & 0.54 & 342 & 25.47 & 313 & 1.72 & 56.7 \\
\hline 31 & 13.9 & 92.63 & 0.50 & 352 & 26.34 & 322 & 2.69 & 56.1 \\
\hline 32 & 13.5 & 92.75 & 0.50 & 368 & 26.66 & 376 & 1.77 & 55.9 \\
\hline 33 & 13.0 & 92.70 & 0.50 & 358 & 26.61 & 265 & 1.28 & 60.3 \\
\hline 34 & 13.8 & 93.22 & 0.47 & 381 & 27.09 & 375 & 1.25 & 57.3 \\
\hline 35 & 13.7 & 92.60 & 0.52 & 351 & 24.97 & 254 & 2.77 & 51.8 \\
\hline 36 & 13.7 & 90.74 & 0.76 & 355 & 28.29 & 329 & 0.93 & 51.2 \\
\hline 37 & 13.1 & 93.11 & 0.52 & 358 & 24.78 & 255 & 2.98 & 51.7 \\
\hline 38 & 13.3 & 93.11 & 0.58 & 399 & 27.06 & 285 & 1.68 & 60.1 \\
\hline 39 & 13.2 & 92.18 & 0.52 & 349 & 28.82 & 308 & 2.29 & 58.6 \\
\hline 40 & 13.2 & 92.70 & 0.51 & 351 & 27.36 & 308 & 1.62 & 56.3 \\
\hline 41 & 13.8 & 92.94 & 0.55 & 362 & 26.29 & 249 & 2.68 & 58.3 \\
\hline 42 & 13.8 & 92.96 & 0.55 & 355 & 26.26 & 321 & 1.98 & 57.7 \\
\hline 43 & 13.6 & 92.60 & 0.53 & 359 & 24.72 & 331 & 2.23 & 56.5 \\
\hline 44 & 13.9 & 93.00 & 0.56 & 385 & 27.49 & 375 & 1.09 & 58.6 \\
\hline 45 & 13.3 & 93.20 & 0.56 & 353 & 24.93 & 364 & 1.93 & 55.5 \\
\hline 46 & 13.9 & 92.92 & 0.55 & 367 & 28.89 & 376 & 1.54 & 58.3 \\
\hline 47 & 13.5 & 91.04 & 0.76 & 354 & 28.03 & 261 & 1.09 & 46.7 \\
\hline
\end{tabular}


Table S1. Reference values obtained by AACC methods (Continuation)

\begin{tabular}{|c|c|c|c|c|c|c|c|c|}
\hline $\begin{array}{l}\text { Sample } \\
\text { number }\end{array}$ & $\begin{array}{c}\text { Moisture } \\
\text { (\%) }\end{array}$ & $\begin{array}{l}\text { Color } \\
\left(L^{*}\right)\end{array}$ & $\begin{array}{l}\text { Ash } \\
\text { (\%) }\end{array}$ & $\begin{array}{l}\text { FN } \\
\text { (s) }\end{array}$ & $\begin{array}{c}\text { Gluten } \\
(\%)\end{array}$ & $\begin{array}{c}W \\
\left(10^{-4} \mathrm{~J}\right)\end{array}$ & $\begin{array}{c}P / L \\
(\mathrm{~mm})\end{array}$ & $\begin{array}{l}\text { IE } \\
(\%)\end{array}$ \\
\hline 48 & 13.4 & 90.58 & 0.85 & 343 & 28.24 & 248 & 1.19 & 43.8 \\
\hline 49 & 13.7 & 92.92 & 0.54 & 391 & 27.71 & 312 & 1.47 & 62.4 \\
\hline 50 & 13.9 & 91.18 & 0.77 & 344 & 28.11 & 349 & 0.96 & 56.4 \\
\hline 51 & 13.4 & 92.57 & 0.69 & 375 & 27.01 & 423 & 1.77 & 52.8 \\
\hline 52 & 13.5 & 90.84 & 0.80 & 359 & 27.99 & 304 & 1.89 & 53.7 \\
\hline 53 & 13.0 & 91.00 & 0.66 & 356 & 27.74 & 257 & 0.60 & 50.9 \\
\hline 54 & 13.9 & 93.04 & 0.50 & 353 & 25.27 & 355 & 2.39 & 57.3 \\
\hline 55 & 13.1 & 90.67 & 0.82 & 342 & 28.72 & 263 & 1.63 & 50.9 \\
\hline 56 & 13.6 & 90.65 & 0.67 & 360 & 28.31 & 300 & 1.02 & 51.0 \\
\hline 57 & 13.5 & 92.74 & 0.55 & 353 & 26.88 & 303 & 1.72 & 57.4 \\
\hline 58 & 13.4 & 90.70 & 0.81 & 340 & 27.25 & 309 & 1.03 & 52.7 \\
\hline 59 & 13.3 & 91.15 & 0.72 & 355 & 27.24 & 337 & 1.82 & 56.3 \\
\hline 60 & 13.7 & 91.37 & 0.73 & 358 & 27.91 & 337 & 1.59 & 61.2 \\
\hline 61 & 14.0 & 92.98 & 0.47 & 362 & 25.87 & 368 & 1.57 & 55.2 \\
\hline 62 & 13.8 & 91.35 & 0.72 & 354 & 27.88 & 228 & 0.51 & 53.5 \\
\hline 63 & 13.3 & 92.90 & 0.49 & 370 & 26.91 & 388 & 1.63 & 56.6 \\
\hline 64 & 13.3 & 90.84 & 0.72 & 363 & 27.30 & 357 & 1.18 & 57.8 \\
\hline 65 & 15.1 & 93.20 & 0.59 & 344 & 25.94 & 377 & 2.48 & 55.5 \\
\hline 66 & 13.5 & 93.08 & 0.48 & 364 & 25.40 & 386 & 1.58 & 58.2 \\
\hline 67 & 14.0 & 92.65 & 0.54 & 368 & 26.51 & 329 & 1.56 & 53.9 \\
\hline 68 & 13.7 & 91.15 & 0.77 & 345 & 27.78 & 341 & 2.19 & 56.6 \\
\hline 69 & 13.8 & 92.74 & 0.55 & 357 & 26.22 & 347 & 1.55 & 56.6 \\
\hline 70 & 13.8 & 92.74 & 0.55 & 357 & 26.22 & 347 & 1.55 & 56.6 \\
\hline 71 & 13.2 & 91.24 & 0.73 & 340 & 28.24 & 299 & 1.92 & 52.9 \\
\hline 72 & 14.0 & 91.57 & 0.62 & 341 & 27.01 & 333 & 1.72 & 56.4 \\
\hline 73 & 13.2 & 90.60 & 0.79 & 348 & 27.94 & 268 & 1.57 & 52.7 \\
\hline 74 & 13.8 & 92.74 & 0.56 & 360 & 25.91 & 325 & 1.81 & 57.0 \\
\hline
\end{tabular}


Table S1. Reference values obtained by AACC methods (Continuation)

\begin{tabular}{|c|c|c|c|c|c|c|c|c|}
\hline $\begin{array}{l}\text { Sample } \\
\text { number }\end{array}$ & $\begin{array}{c}\text { Moisture } \\
\text { (\%) }\end{array}$ & $\begin{array}{l}\text { Color } \\
\left(L^{*}\right)\end{array}$ & $\begin{array}{l}\text { Ash } \\
\text { (\%) }\end{array}$ & $\begin{array}{l}\text { FN } \\
\text { (s) }\end{array}$ & $\begin{array}{c}\text { Gluten } \\
(\%)\end{array}$ & $\begin{array}{c}W \\
\left(10^{-4} \mathrm{~J}\right)\end{array}$ & $\begin{array}{c}P / L \\
(\mathrm{~mm})\end{array}$ & $\begin{array}{l}\text { IE } \\
(\%)\end{array}$ \\
\hline 75 & 14.0 & 92.73 & 0.54 & 373 & 26.72 & 373 & 1.14 & 55.8 \\
\hline 76 & 13.3 & 90.59 & 0.84 & 375 & 28.49 & 343 & 0.85 & 57.1 \\
\hline 77 & 13.5 & 92.65 & 0.55 & 386 & 26.99 & 263 & 1.82 & 55.2 \\
\hline 78 & 13.6 & 92.91 & 0.54 & 351 & 26.98 & 366 & 1.21 & 57.0 \\
\hline 79 & 14.4 & 93.30 & 0.40 & 368 & 29.55 & 316 & 2.18 & 58.3 \\
\hline 80 & 13.5 & 93.00 & 0.55 & 368 & 26.48 & 346 & 2.03 & 56.8 \\
\hline 81 & 14.1 & 92.60 & 0.50 & 368 & 29.3 & 283 & 2.30 & 55.8 \\
\hline 82 & 13.2 & 90.83 & 0.59 & 347 & 30.15 & 286 & 1.21 & 52.2 \\
\hline 83 & 12.8 & 92.72 & 0.48 & 368 & 27.29 & 305 & 1.74 & 57.3 \\
\hline 84 & 13.8 & 93.01 & 0.50 & 368 & 28.26 & 311 & 2.09 & 52.9 \\
\hline 85 & 12.8 & 92.50 & 0.45 & 368 & 27.29 & 346 & 1.31 & 58.8 \\
\hline 86 & 13.9 & 92.90 & 0.41 & 368 & 26.39 & 316 & 1.43 & 61.2 \\
\hline 87 & 13.1 & 90.99 & 0.71 & 358 & 27.91 & 337 & 1.59 & 61.9 \\
\hline 88 & 13.5 & 92.80 & 0.46 & 354 & 27.09 & 304 & 2.25 & 56.7 \\
\hline 89 & 13.0 & 90.23 & 0.72 & 337 & 28.09 & 239 & 1.07 & 48.0 \\
\hline 90 & 13.3 & 91.00 & 0.76 & 344 & 28.90 & 282 & 1.26 & 56.5 \\
\hline 91 & 12.9 & 92.74 & 0.51 & 365 & 26.82 & 339 & 1.67 & 55.0 \\
\hline 92 & 14.3 & 92.70 & 0.52 & 368 & 31.01 & 344 & 2.06 & 60.4 \\
\hline 93 & 13.3 & 90.59 & 0.84 & 375 & 28.49 & 343 & 0.85 & 57.1 \\
\hline 94 & 12.7 & 92.60 & 0.48 & 368 & 26.34 & 305 & 2.92 & 54.7 \\
\hline 95 & 13.8 & 93.00 & 0.53 & 363 & 28.95 & 284 & 3.48 & 56.0 \\
\hline 96 & 13.4 & 90.93 & 0.70 & 342 & 28.3 & 265 & 1.19 & 51.6 \\
\hline 97 & 13.5 & 91.05 & 0.79 & 345 & 29.83 & 313 & 1.55 & 55.2 \\
\hline 98 & 13.9 & 92.12 & 0.57 & 368 & 27.55 & 401 & 2.00 & 59.4 \\
\hline 99 & 12.4 & 93.40 & 0.47 & 358 & 26.59 & 320 & 1.97 & 58.1 \\
\hline 100 & 12.4 & 93.40 & 0.47 & 358 & 26.59 & 320 & 1.97 & 58.1 \\
\hline
\end{tabular}




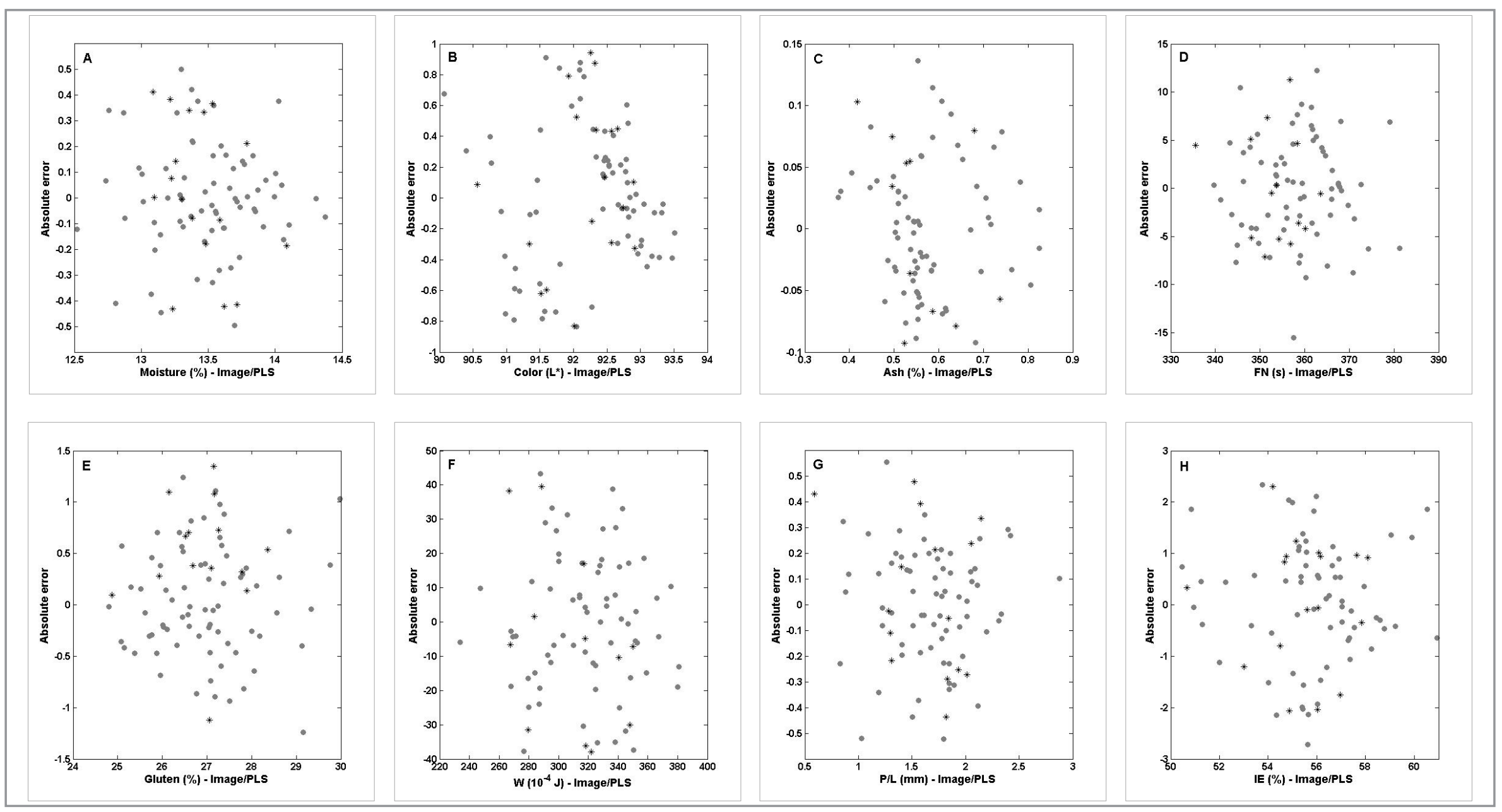

Figure 1S. Residuals. (A) Moisture. (B) Color. (C) Ash. (D) FN. (E) Gluten. (F) W. (G) P/L. (H) IE. $(\bullet)$ calibration samples. $(*)$ external validation samples. 


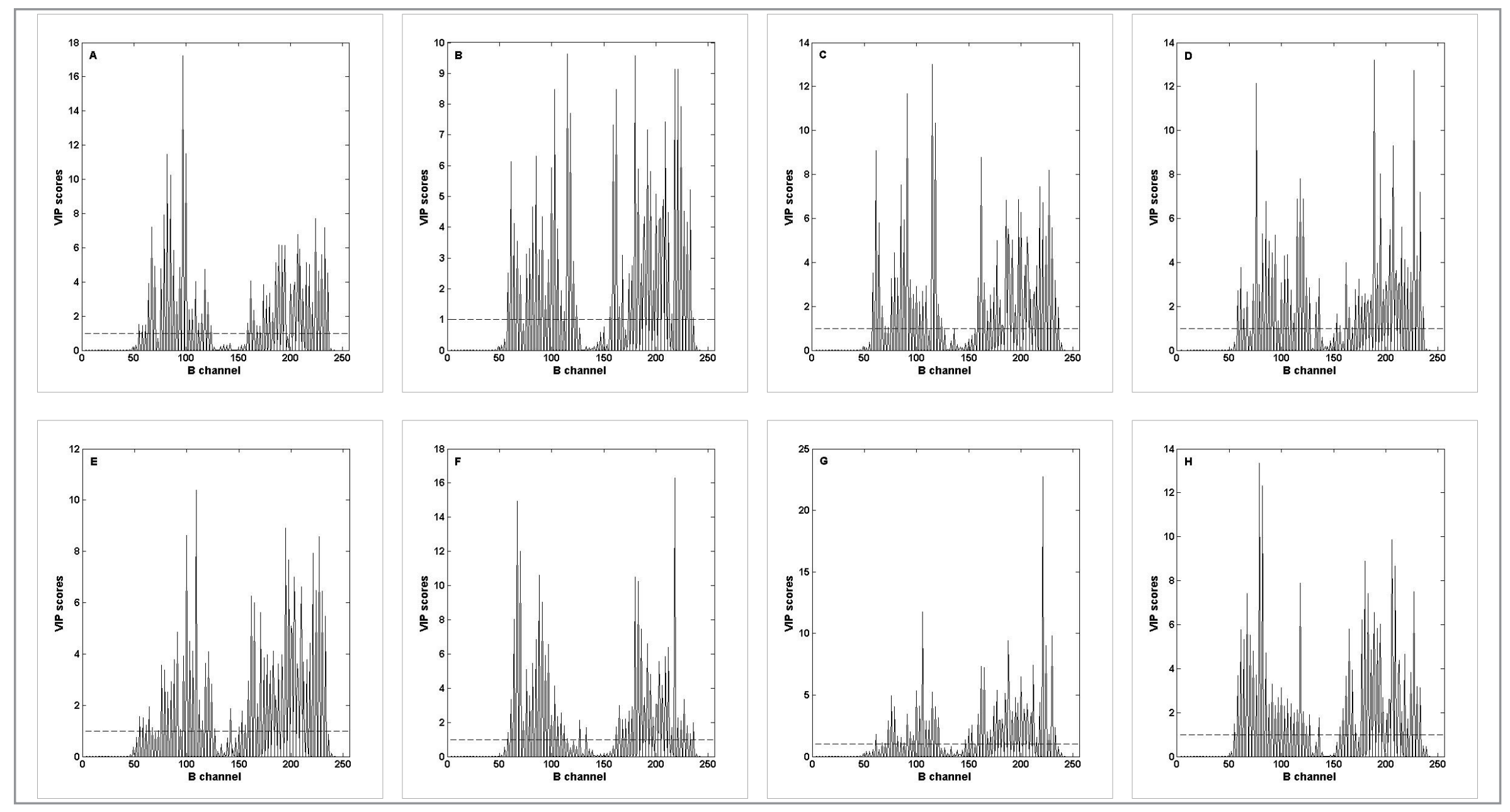

Figure 2S. VIP scores. (A) Moisture. (B) Color. (C) Ash. (D) FN. (E) Gluten. (F) W. (G) P/L. (H) IE. 